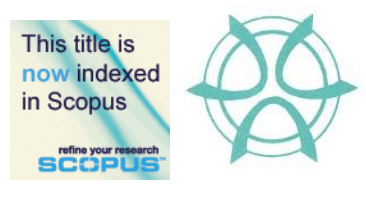

PLANNING MALAYSIA:

Journal of the Malaysian Institute of Planners

VOLUME 17 ISSUE 1 (2019), Page 205 - 218

\title{
THE APPLICABILITY OF LAND ALLOCATION APPROACH FOR POST-DISASTER HOUSE CONSTRUCTION IN KUALA KRAI
}

\author{
Mohamad Haizam Mohamed Saraf ${ }^{1}$, Thuraiya Mohd ${ }^{2}$, Siti Fairuz Che

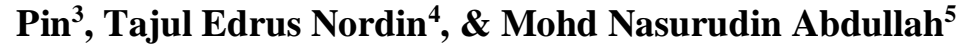 \\ 1, 2, 3,4,5 Faculty of Architecture, Planning \& Surveying \\ UNIVERSITI TEKNOLOGI MARA, PERAK BRANCH, MALAYSIA
}

\begin{abstract}
Despite 2,374 units of houses were destroyed during the 2014 major floods in Kelantan, the governments had only manage to build 143 units of post-disaster houses due to lack of land to accommodate the flood victims because of land ownership constraints. Current practice of post-disaster house reconstruction in Malaysia only accommodate victims with land ownership. The flood victims without land do not have the means or money to buy new land for the construction of the post-disaster house. A land allocation policy for victims without land has yet to be introduced in Malaysia. Using a case study approach, the thrust of this research is to highlight the need of land allocation approach for the flood victims who are without land for post-disaster house construction. Therefore, a semistructured interview was conducted on twelve experts, from the field of land law, policies and administrations, to gauge their perceptions in the applicability of land allocation approach in post-disaster house construction. Data from the interviews were analysed using content analysis technique. Findings from the analysis showed that the experts recommended the state alienation approach in accordance with National Land Code 1965 to allocate land for an emergency, temporary shelters and post-disaster house construction. Land allocation policy can assist government in ensuring that land to shelter disaster victims can be made available after the disaster.
\end{abstract}

Keywords: post-disaster house construction, land allocation approach, land allocation policy 
Mohamad Haizam Mohamed Saraf, Thuraiya Mohd, Siti Fairuz Che Pin, Tajul Edrus Nordin, \& Mohd Nasurudin Abdullah The Applicability of Land Allocation Approach for Post-Disaster House Construction in Kuala Krai

\section{INTRODUCTION}

In the post-disaster reconstruction and rehabilitation phase, many disaster prone areas do not have land that is allocated for the purpose of emergency, temporary shelter and new permanent houses (Mijoni, 2009). Besides, acquiring land to accommodate the disaster victims who do not own land for the construction of new permanent house is often a difficult task in many countries $(\mathrm{Hu}, \mathrm{Sheu}, \&$ Xiao, 2014).

Most government do not maintain land allocation policies for the purpose of constructing post-disaster houses. For instance, in Haiti, lack of government policy and regulatory system had slowed down post-disaster shelter responses. There was no system for coordinating the damage assessment, which eventually determined at more than 400,000 buildings. As a result, the government had to create a unit, by attaching it to public works department and create policies regarding technical damage assessment which prolonged the reconstruction efforts (Leckie, 2011).

Similarly in Malaysia, there is often a lack of authority to provide land for the purpose of emergency, temporary shelters and new permanent house construction (National Disaster Management Agency, 2015). Thus, post-disaster relocation, such as flood victims relocation in Kelantan, Terengganu and Pahang, often opt out victims who do not own land (Chan, 1995). A land allocation approach to include all displaced victims has yet to be introduced in Malaysia (National Disaster Management Agency, n.d).

\section{Land Allocation Approach in Post-Disaster Management}

The absence of land allocation policy slows down post-disaster recovery efforts (Thomas, 2015). Because of lack of regulatory policies, it took far longer than necessary to establish land allocation policies (Leckie, 2011; Mohd, Fathi, Harun, $\&$ Chong, 2018). Forward looking land allocation policy can provide immediate location for the purpose of emergency, temporary shelters and new permanent house construction. Clear legal and policy frameworks on these issues prior to the occurrence of disaster can greatly facilitate eventual shelter programming by the international community (Thomas, 2015).

\section{Land Allocation Practices in Malaysia and Other Countries}

This section summarises post-disaster land allocation approaches in several countries including Malaysia.

\section{Rwanda Republic}

In Rwanda, according to the National Land Policy, all Rwandese enjoy the same rights of access to land, without discrimination against women or any other vulnerable persons. Vulnerable persons in disaster cases refer to the affected persons and they are eligible for resettlement under government projects. All 
PLANNING MALAYSIA

Journal of the Malaysia Institute of Planners (2019)

those affected persons whose family land/ houses/ business premises/ services or buildings that are located within the identified disaster prone areas will be acquired and compensated accordingly under the resettlement projects. It applied to all group of victims, the owners, renters or homeless (Republic of Rwanda, 2016).

The allocation of land is made available with the compliance of the procedure laid under Article 12 of The Expropriation Law. It stipulates that The Expropriation Law provides land for public interests, which includes resettlement projects as laid down under Article 5 of the Law (Republic of Rwanda, 2016). The only issue is the land will be acquired after the disaster had occurred. As a result, the reconstruction for post-disaster house takes far longer than necessary and the disaster victims will be staying in their temporary shelters until the land has been acquired for the purpose of post-disaster house reconstruction.

\section{The Philippines}

In the Philippines, the local governments had already drafted a relocation plan and disposed of land for housing the victims who have land ownership constraints in the post-disaster house construction (Carrasco et al., 2016). For temporary shelters while the victims wait for the completion of the post-disaster house, the private institutions will lease land for the purpose of providing land for emergency temporary shelters.

It is an advantage to have land available before a disaster strikes for temporary and new permanent house construction although there are some issues relating to the location of the resettlement sites which are away from the towns. The allocated land allows a quick start to the construction of new permanent houses to the evacuees, especially those without formal legal rights on the land they were occupying (Carrasco et al., 2016).

\section{Bangladesh}

In Bangladesh, land acquisition is used to allocate land for resettlement projects. The policies and guidelines also provide resettlement assistance to all the affected persons, irrespective of their land ownership status based on the Post Flood Jamuna Project model. The policy also states that the lack of legal documents for customary rights of occupancy or titles shall not affect the eligibility of the affected persons in the resettlement projects (Bangladesh Water Development Board, 2014). All affected persons as mentioned in the policies and guidelines will be eligible for compensation and assistance to be provided through the resettlement projects.

\section{Islamic Republic of Pakistan}

The Land Acquisition Act 1984 of Pakistan (with successive amendments) enables the government to acquire land for an emergency basis that includes 
Mohamad Haizam Mohamed Saraf, Thuraiya Mohd, Siti Fairuz Che Pin, Tajul Edrus Nordin, \& Mohd Nasurudin Abdullah The Applicability of Land Allocation Approach for Post-Disaster House Construction in Kuala Kra

resettlement areas for disaster evacuees who lost their houses to the disaster (Islamic Republic of Pakistan, 2011). The land is allocated through acquisition following a disaster and the resettlement project is estimated to complete within two years. This provision ensures the immediate start of temporary shelters and reconstruction of post-disaster house following a disaster. However, only registered proprietor flood victims or customary rights holders are eligible for the resettlement project.

\section{Republic of Haiti}

The lack of land allocation policy in Haiti after the earthquake in 2010 was a wakeup call for the country as there was no system to coordinate the damage assessment which involved more than 400,000 affected buildings and could not provide an adequate place for shelter programmes which lengthen the postdisaster reconstruction effort (Leckie, 2011). After that, the republic has created a body to create land policies for the purpose of emergency, temporary shelters and post-disaster house construction. The policy provides post-disaster technical damage assessment, approach to allocate land for reconstruction and rehabilitation phase, temporary shelters and housing design for the displaced persons. The approach the Republic uses is through land disposal by the government for the purpose of emergency, temporary shelters and post-disaster house construction (ibid).

\section{Indonesia}

11,900 houses were destroyed by the 2004 Tsunamis in Acheh. To coordinate the recovery efforts, Indonesian government had created a Reconstruction and Rehabilitation Agency (BRR). The main issue in the reconstruction effort is that most of the areas in Acheh were no longer environmentally safe or desirable to be rebuilt. Thus, the government initial policy is to enforce the "No Build Zones" about 300 to 1,000 metres from the new shoreline. According to the policy, reconstruction for those previously living in these areas, many of whom were registered owners, would be relocated by the government.

About 30,000 tsunamis victims were unable to rebuild their houses on their pre-disaster land due to the No Build Zones policy and geological changes as some of their land have been permanently submerged. All the victims, including renters were relocated to new safer location through an acquisition of replacement land to the victims who are the land owners and provision for land tenure for victims who are renters and informal settlers (Wegelin, 2006).

\section{Malaysia}

As post-disaster land allocation policy is yet to be introduced in the country's disaster management, the approach for 2004 tsunami post-disaster house reconstruction is reviewed. The worst affected areas were in Penang and Kedah, 
which involved 328 units of destroyed houses. Post-disaster house assistance were funded under the National Disaster Relief Fund. However, land ownership constraints among the tsunami victims have delayed the construction of the houses. The approaches taken by the government and non-governmental organisations in tackling the issue of victims who were non-land owners are summarised in Table 1.

Table 1: Malaysia approach in post-tsunami house reconstruction by location

\begin{tabular}{lccc}
\hline Type of victims & $\begin{array}{c}\text { Tanjung Bungah, } \\
\text { Penang }\end{array}$ & Kuala Muda, Kedah & Langkawi, Kedah \\
\hline $\begin{array}{l}\text { Victims with land } \\
\text { ownership }\end{array}$ & $\begin{array}{c}\text { A new post-disaster } \\
\text { house funded by the } \\
\text { Federal Government } \\
\text { under the National } \\
\text { Disaster Relief Fund } \\
\text { built on the land they } \\
\text { owned. }\end{array}$ & $\begin{array}{c}\text { A new post-disaster house } \\
\text { funded by the Federal } \\
\text { Government under the } \\
\text { National Disaster Relief } \\
\text { Fund built on the land they } \\
\text { owned. }\end{array}$ & $\begin{array}{c}\text { A new post-disaster } \\
\text { house funded by the } \\
\text { Federal Government } \\
\text { under the National } \\
\text { Disaster Relief Fund } \\
\text { built on the land they } \\
\text { owned. }\end{array}$ \\
\hline $\begin{array}{l}\text { Victims without land } \\
\text { ownership }\end{array}$ & $\begin{array}{c}\text { State government } \\
\text { provides land and a few } \\
\text { blocks of low cost } \\
\text { apartments donated by } \\
\text { public fund. }\end{array}$ & $\begin{array}{c}\text { State government provides } \\
\text { land and a basic low cost } \\
\text { house for each of the } \\
\text { renters and informal } \\
\text { settlers. }\end{array}$ & $\begin{array}{c}\text { Not applicable as all } \\
\text { the victims were } \\
\text { registered owners. }\end{array}$ \\
\hline Source: Public Works Department $(2015)$ & &
\end{tabular}

In Penang, as there was no land allocated for emergency purpose, the state government provided land for the resettlement project to help 133 displaced persons whom without land ownership. Low cost apartments were built on that land, funded through public donation. The total cost for the land, apartments, and basic utilities and facilities were RM80 million.

Similarly in Kota Kuala Muda, to accommodate the non-land owners, the government gave a piece of land and a basic house for each of them. The total costs of the relocation project amounted to RM20 million, including the cost of utilities, sewage plant, sewerage and other facilities. In Langkawi however, all the victims who had lost their houses to tsunamis were registered owners. Therefore, the construction of the post-disaster house was not an issue.

In Kuala Krai, due to flood, the cost to relocate all the 328 victims who were non-land owners was approximately about RM100 million. The delay to provide new permanent houses for the flood victims of Kuala Krai was simply because the scale of destruction was bigger, which involved 1,850 units of destroyed houses. With no land allocated for such purpose in pre-disaster planning, the reconstruction effort took far longer than necessary to be completed. Even 3 years after the flood, there are still flood victims who are living in temporary shelters and waiting for the post-disaster house assistance. The need for land allocation policy is obligatory as a solution in the post-disaster house reconstruction (Leckie, 2011; Thomas, 2015; Carassco, et. al, 2016). 
Mohamad Haizam Mohamed Saraf, Thuraiya Mohd, Siti Fairuz Che Pin, Tajul Edrus Nordin, \& Mohd Nasurudin Abdullah The Applicability of Land Allocation Approach for Post-Disaster House Construction in Kuala Krai

\section{The Need of Land Allocation Policy in Post-Disaster Context}

Fitzpatrick, Dunn and Sanders (2008) articulated that in the post-disaster settings, land for building emergency, transitional and new permanent housing must be a priority. This is seconded by Leckie (2011) who stressed that to acquire new land following certain types of disasters, most notably severe flooding and tsunamis, is paramount because considerable amounts of land can be physically lost. In spite of all the flood rehabilitation and reconstruction management in Malaysia, the land allocation for emergency, temporary shelters and new permanent houses is still found lacking in post-disaster management.

In Malaysia, insufficient policy regarding land allocation for emergency purposes in Malaysian law is simply because Malaysia seldom has major disaster events. The major flood that hit Kelantan in December 2014 should be taken seriously in improving post-disaster recovery efforts in Malaysia. Through several reviews on the existing land allocation policies from different countries, it seems appropriate for Malaysia to consider land allocation policy in the flood disaster management under the land policy and land law. There are two approaches to make land available before a disaster strikes; 1 ) a provision under the state power to dispose of land as stipulated under Section 42 of the National Land Code 1965 and 2) the acquisition of land as laid down under the Land Acquisition Act 1960.

In Malaysia, land matters are under the purview of the state government as stipulated under the Ninth Schedule, List 2, Item 2 of the (Federal Constitution, p.272). The state authority has the right to gazette any state land for the public purpose with accordance to Section 62 of the National Land Code 1965 (p.79). In terms of legal aspect, the state authority can gazette any state lands for public purpose, in this case the land allocation for disaster reconstruction and rehabilitation phase.

Federal and state authorities also have the right to acquire land through Land Acquisition Act 1960 if necessary. As provided under Section 3(c) of the Land Acquisition Act 1960, government can acquire private land for mining, residential, agriculture, commercial or industrial purposes. The only issue is the interpretation of residential purpose does not further explain that the land can be acquired for an emergency, temporary shelters or new permanent houses. Established cases like Petaling Rubber Estates Ltd. vs. Pemungut Hasil Tanah Kedah, Pemungut Hasil Tanah Kuantan vs. Nor Cahaya Bt Ab. Majid and Oriental Rubber and Oil Palm Sdn. Bhd only discussed the acquisition involved were for the purpose of low cost residential housing schemes. If the land can be acquired for an emergency, temporary shelters and post-disaster new permanent houses reconstruction purposes, people who their lands are acquired cannot question the intention to acquire, except in the matters of adequate compensation (Abdul Aziz Husin, 1996). 
PLANNING MALAYSIA

Journal of the Malaysia Institute of Planners (2019)

From the legal aspects (Federal Constitution, National Land Code and Land Acquisition Act), the state authority has the ability to make land available for resettlement purposes in accordance to the National Land Code 1965, and any larger institutions can acquire land for acquisition if the interpretation of Section 3(c) of the Land Acquisition Act 1960 includes emergency nature such as disasters. Then, the land allocation can be made available before a disaster strikes. This will accelerate the process in providing new permanent houses for flood victims, regardless if the flood victims have own land or are landless.

\section{RESEARCH METHODOLOGY}

The aim of this research is to recommend a land allocation approach for the Kuala Krai, Kelantan flood victims who are without land ownership. Thus, this research applies case study approach to gauge the appropriate land allocation approach. As this research only focuses on the applicability of land allocation approach to accommodate flood victims without land ownership, a case study approach was used. To solve the issue of the lack of land allocation approach in post-disaster house reconstruction, in-depth semi-structured interview with related experts was conducted.

\section{Data Collection}

The questions used to guide the interview sessions were developed from Creswell and Plano's (2006) guidelines for developing and asking effective interview questions. The guided questions were:

1. Which approach of land allocation do you think is relevant in Malaysian context?

2. What aspects of this approach make it as a preferred approach to allocate land for emergency, temporary shelter and post-disaster new permanent houses?

3. What aspects of this approach, if any, do you find lacking or in need of modification?

4. Are there any other aspects of land law and policies that you would like to discuss?

This list of four questions was not comprehensive but only serves to achieve the research objective that is to recommend the applicability of land allocation approach to accommodate the flood victims who do not have land ownership. In addition, related secondary data were also sourced from published documents and existing Acts.

\section{Data Analysis}

The interviews were translated into English and were transcribed into electronic format (Microsoft Word). Subsequently, open coding method was used to analyse 
Mohamad Haizam Mohamed Saraf, Thuraiya Mohd, Siti Fairuz Che Pin, Tajul Edrus Nordin, \& Mohd Nasurudin Abdullah The Applicability of Land Allocation Approach for Post-Disaster House Construction in Kuala Krai

the transcribed data. The data were coded or grouped by determining keywords and phrases that were common amongst the interviewees. Throughout the coding process, the phrases and keywords were analysed and encoded with suitable category labels and afterwards, commonalities were developed (Saldana, 2009).

Folkestad (2008) argues that this coding analysis helps researcher to build concepts and categories from entire document. The output is to build a descriptive preliminary framework for later analysis. As it builds directly from the raw data, the process itself ensures the validity of the work (Bryman, 2012). Miles and Huberman (1994) also suggest that to further analyse the results from the coding process, the data reduction is split into entities which in turn will be put into categories.

Finally, the categories from the content analysis were again reviewed and then triangulated to present the conceptual framework of land ownership constraints (the second objective) and the most recommended land allocation approach for emergency, temporary shelters and post-disaster new permanent houses (the third objective). These new emergent findings were narrated to relate to the implications of the research.

\section{FINDINGS}

As aforementioned, there are two possible approaches that can be applied in Malaysia to allocate land for an emergency, temporary shelter and post-disaster house construction for the vulnerable groups (the landless, poor, disabled, indigenous and elderly). They are the state alienation with accordance to Section 42 of the National Land Code 1965 and land acquisition under the provision of Section 3 of the Land Acquisition Act 1960. All the interviewees agreed that state alienation is preferred over land acquisition. The recommendation of land allocation approach for an emergency, temporary shelters and post-disaster house construction is summarised in Figure 2. acquisition

\section{The Recommended Land Allocation Approach for Post-disaster House Construction}

The aspects of the preferred state alienation approach were justified in two aspects; they are legally right and technically efficient if compared to land acquisition approach for emergency, temporary shelters and new permanent house construction purposes.

Two participants mentioned the Section 2 under the List 2 of the $9^{\text {th }}$ Schedule of the Federal Constitution that articulates that land matters are under the jurisdiction of the state government. The other participant further added that as land is a state matter, the Federal Government cannot intervene in making the land allocation for the said purpose. Above all, it is legally permissible for the state government to allocate land for the purpose. Below are the excerpts from the selected participants. 
PLANNING MALAYSIA

Journal of the Malaysia Institute of Planners (2019)

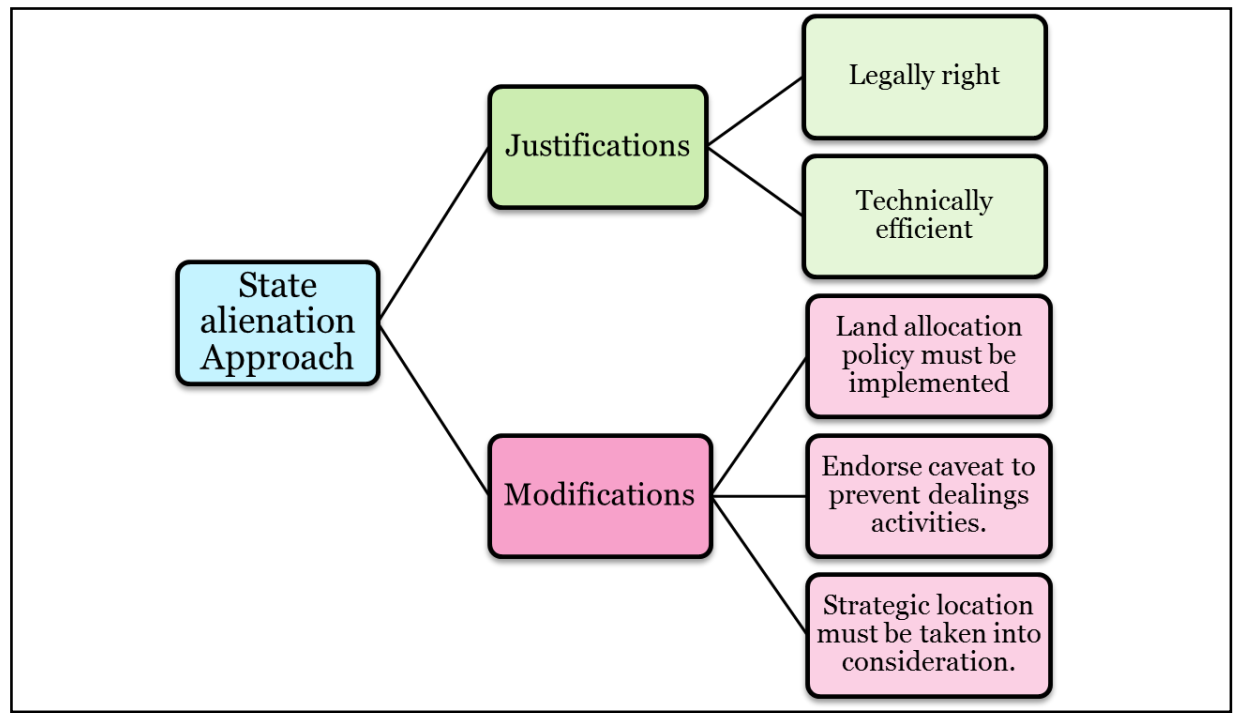

Figure 2: The recommended land allocation approach for emergency, temporary shelters and post-disaster house construction in Kelantan

"Look at Section 2 under the $9^{\text {th }}$ Schedule. The Federal Constitution states that any state land is under the power of the state government. If the preface you gave me on the email earlier that the ways to provide land for disaster are acquisition and state disposal, I think the state should be responsible to providing land for disaster purpose." [N1]

"Land is a state matter. So legally, to make land available for the purpose of disaster [referring to the land allocation for an emergency, temporary shelters and new permanent houses] is possible by the state [government]." [N3]

"In my opinion this is the best approach because the state land is owned by the state government. So it can be disposed by alienation to the flood victims, and the process will be not complicated." [N9]

"Legally, to make land available for the purpose of disaster [referring to the land allocation for an emergency, temporary shelters and new permanent houses] is possible by the state [government]. [N11]

One of the participants said that the Kelantan land law is governed by the National Land Code 1965 and with accordance to Section 40 of the Code, it has the power to alienate land for many purposes as stipulated under the Section 42 of the Code. 
Mohamad Haizam Mohamed Saraf, Thuraiya Mohd, Siti Fairuz Che Pin, Tajul Edrus Nordin, \& Mohd Nasurudin Abdullah The Applicability of Land Allocation Approach for Post-Disaster House Construction in Kuala Krai

"The first thing is if you go way back to the Malaysia land law, the land is under the state's power. The power is written under the Section 40 of the National Land Code [1965]. You see, the land law in Peninsular [Peninsular states] is governed under the National Land Code. When it comes to alienation of land, state [government] has the right to dispose land for reservation of land and other rights under Section 42 of the Code." [N5]

Besides, the state government must take care of its people's quality of life and must not let them stay in the temporary shelters for long, which will make them more vulnerable. This is because the temporary shelters are not built to last long. Additionally, the shelters are erected on someone else's land and the settlers are at risk of eviction if they keep staying on that land.

"I think land allocation for such purpose should be provided by the state government [state alienation through the disposal of land]. It's their people; they need to have a holistic approach in the post-disaster housing construction." [N6]

"Take temporary shelters as an example. Most of the temporary shelters in Kuala Krai are built for a temporary purpose, but the constructions of new homes for the victims are taking far longer time than necessary because of land issues. This makes the victims who are landless expose to eviction by the land owners." [N10]

Equally important, all participants agreed that state alienation costs less, is quicker and involves less paperwork, which makes it technically more efficient than the land acquisition approach.

"If you compare state disposal [alienation] and the second approach [land acquisition], the cost is greater if an acquisition is chosen. Because it will involve the affected persons or bodies whom their lands are being acquired, the scheduled land must be adequately compensated." [N1]

"It would be hassle free in terms of land administration and also involve less cost if the state government provides land for post-disaster context with the existing reserved state lands" [N2]

"If we use the land acquisition approach, the cost will be high." [N3]

"Theoretically we can use this approach, but it will involve a significantly higher cost." [N4] 
PLANNING MALAYSIA

Journal of the Malaysia Institute of Planners (2019)

"Land acquisition approach will be quite difficult because it involves other people's land." [N5]

"Approach of land acquisition will incur a high cost and is time consuming..." [N6]

Although state alienation is the preferred land allocation approach, some improvements need to be done to acknowledge that the land allocation is for emergency, temporary shelters and new permanent house purpose in the state's jurisdiction.

"Such land [emergency, temporary shelters and new permanent houses] can be made available under Section 62 that says the state can reserve any of the state lands for public purposes, however it must comply with the Section 62(2) requirements. The reservation must be detailed, the purpose...the "public purpose" term. It is not written in the Code. Well in this case..., for disaster purpose." [N3]

"...because the law allows the state [government] to do so. Above all, the land belongs to the state [government]. Next thing is the state [government] has the power to dispose of land for land reservation and ownership of land." [N2]

"But for disaster context, does the reservation of land under section 62 allow any of the state lands to be reserved for emergency disaster purpose?" [N8]

"...relevant bodies need to propose the existing law to be amended to include the emergency, [temporary] shelters and new [permanent] homes as public purposes. Except if there are already existing cases of law that had already interpreted such purpose as the public purpose." [N9]

\section{The Applicability of Land Allocation Approach in Malaysia's Post-disaster House Construction}

Although the importance of land allocation approach for post-disaster purpose was established during the interviews, some measures need to be addressed before the implementation of the approach. To begin with, a land allocation policy must come into force. The participants addressed that with the land allocation policy, land can be made available before a disaster strikes. This will immediately assist vulnerable groups such as the elderly, disabled and victims without land ownership in the post-disaster house construction. The participants 
Mohamad Haizam Mohamed Saraf, Thuraiya Mohd, Siti Fairuz Che Pin, Tajul Edrus Nordin, \& Mohd Nasurudin Abdullah The Applicability of Land Allocation Approach for Post-Disaster House Construction in Kuala Kra

were also concerned with the victims who built temporary shelters on private or state lands who will be evicted if the process to acquire land for them takes a long time.

"Land allocation policy must be introduced in the resettlement framework. What worries me is most of the temporary shelters in Kuala Krai are built for temporary purpose, but the constructions of the new homes for the victims are taking far longer than necessary because of land constraints. But if the government has allocated land for an emergency; all the aids, shelters and post house construction can be immediately provided and the landless victims will be not overlooked." [N1].

"The existing legal framework is not particularly helpful or well written when it comes to renters. Because of this problem, (the) policy in the post-disaster housing construction must be enhanced (so) that (it) will include all disaster victims irrespective of their land titles." [N3]

"I would also suggest, if possible, identify plots of land for a temporary use beforehand. This is all pre-disaster land policy planning". [N4]

Secondly, the resettlement program must take into consideration the fact that the houses could be sold after the victims obtained the land and the new permanent houses. The government can endorse a caveat for a period of time, such as 10 years to prevent sale of the house by the victims. The house must also be occupied by the victims and not rented out. Any rental activities must be prohibited.

"...they need to stay there for more than five or six years to prevent the occurrence of buying and selling in a short time period. The alienated land must be inserted with (a) caveat up to 10 years. "[N5]

"Most importantly we have to make sure that the person who receives this land is really eligible to avoid fraudulent people who take advantage of the mercy of the state and federal provisions. "[N7]

Another highlight is that the land allocated for such purpose must be strategic, safe and has access to facilities such as schools, groceries and health care. This is because currently the resettlement for the 2014 flood victims is situated at flood prone areas and quite remote from Kuala Krai Town. This will discourage victims to settle at the designated place. 
PLANNING MALAYSIA

Journal of the Malaysia Institute of Planners (2019)

\begin{abstract}
"The evacuation area is still an area at risk of flooding. Federal land [resettlement for 2014 flood victims] in Sungai Durian was also affected by the flood in year 2014. The Telekong resettlement program is also a flood-prone area, also located remote from the town [Kuala Krai] as it is near the forest reserved land." [N12]
\end{abstract}

\title{
CONCLUSION
}

The availability of land will allow the immediate start of the post-disaster new permanent house construction in the resettlement areas. The state land is under the State authority jurisdiction as provided under the Federal Constitution (List 2 Ninth Schedule). If the state government can dispose land under the reservation of land, it is also possible for it to dispose of land for the purpose of post-disaster emergency, temporary shelters and new permanent houses.

This approach will provide land bank for an emergency. In Pakistan (the 2005 earthquake) and India (the 2001 Gujarat earthquake), for example, a lot of government-owned land made available quickly after the disaster for temporary shelters. Moreover, some NGOs actually bought land specifically to be used for temporary and permanent shelter in the post-disaster context.

Above all, the flood risks cannot be fully eliminated despite many mitigation programmes which have been executed by both federal and state governments. Thus, this land allocation approach through state alienation of land is a forward looking approach in providing land for an emergency, temporary shelters and post-disaster house construction.

The recommended approach cannot be implemented if there is no proposal being made to introduce land allocation policy in the disaster management policies. The land allocation policy for an emergency, temporary shelters and new permanent house construction needs to be integrated with the flood or disaster policies and related written laws. Therefore, in depth studies are recommended for an effective formulation of the land allocation policy for emergency, temporary shelters and post-disaster house construction in Malaysia.

\section{ACKNOWLEDGEMENT}

The researchers would like to extend their gratitude to the Ministry of Finance for funding this research under the National Property Research Grant (NaPReC).

\section{REFERENCES}

Abdul Aziz Husin (1996). Undang-undang pemerolehan dan pengambilan tanah. Kuala Lumpur: Dewan Bahasa dan Pustaka.

Bangladesh Water Development Board (2014). Resettlement framework: Flood and riverbank erosion risk management investment program. Chandpur: Author.

Bryman, A. (2012). Social research methods $\left(4^{\text {th }}\right.$ edition). New York: Oxford University Press. 
Mohamad Haizam Mohamed Saraf, Thuraiya Mohd, Siti Fairuz Che Pin, Tajul Edrus Nordin, \& Mohd Nasurudin Abdullah The Applicability of Land Allocation Approach for Post-Disaster House Construction in Kuala Krai

Carrasco, S., Ochiai, C., \& Okazaki, K. (2016). Disaster induced resettlement: Multistakeholder interactions and decision making following tropical storm Washi in Cagayan de Oro, Philippines. Procedia - Social and Behavioral Sciences, 218, 35-49.

Chan, N. W. (1995). Flood disaster management in Malaysia: An evaluation of the effectiveness of government resettlement schemes. Emerald Insight, 4(4), 2229.

Creswell, J. W., \& Plano Clark, V. L. (2006). Designing and conducting mixed methods research. Thousand Oaks, CA: Sage.

Fitzpatrick, M. C., Dunn, R. R., \& Sanders, N. J. (2008). Data sets matter, but so do evolution and ecology. Global Ecology \& Biogeography, 17(4), 562-565.

Folkestad, B. (2008). Analysing interview data: Possibilities and challenges. Eurosphere Online Working Paper Series, 13, 1-18.

Hu, Z. H., Sheu, J. B., \& Xiao, L. (2014). Post-disaster evacuation and temporary resettlement considering panic and panic spread. Transportation Research Part B: Methodological, 69, 112-132.

Islamic Republic of Pakistan. (2011). Land acquisition and resettlement framework. (n.p.): (n.p.).

Leckie, S. (2011). Regulatory obstacles to rapid and equitable emergency and interim shelter solutions after natural disasters. Retrieved from https://www.ifrc.org/PageFiles/125636/ Displacement\%20Solutions\%20$\%$ 20Regulatory\%20Barriers.pdf.

Mijoni, P. L. (2009). Management of floods in Malawi: Case study of the Lower Shire River Valley. Disaster Prevention and Management: An International Journal, 18(5), 490-503.

Miles, M. B., \& Huberman, A. M. (1994). Qualitative data analysis an expanded sourcebook ( $2^{\text {nd }}$ edition). London: SAGE Publications Ltd.

Mohd, S., Fathi, M. S., Harun, A. N., \& Chong, N. O. (2018). Key issues in the management of the humanitarian aid distribution process during and postdisaster in Malaysia. Planning Malaysia, 16(1), 211-221.

National Disaster Management Agency (n.d.). Disaster Portal. Retrieved 13 February 2016, from http://portalbencana.ndcc.gov.my/Portal/Disaster

Public Works Department Malaysia. (2015). Persidangan Pengurusan Bencana Banjir Kelantan 2015. Kuala Lumpur.

Republic of Rwanda. (2016). Resettlement policy framework.

Saldana, J. (2009). The coding manual for qualitative researchers. London: SAGE Publications Ltd.

Thomas, A. (2015, June 11). Resettlement in the wake of Typhoon Haiyan in the Philippines: A strategy to mitigate risk or a risky strategy? Retrieved from https://www.brookings.edu/research/resettlement-in-the-wake-of-typhoonhaiyan-in-the-philippines- a-strategy-to-mitigate-risk-or-a-risky-strategy

Wegelin, E. A. (2006). Post tsunami reconstruction in Indonesia. In D. M. A. Weiss \& N. Sedmark-Weiss (Eds.), Global urban development (pp. 1-6). Retrieved from www.globalurban.org/GUDMag2006Vol2Iss1/Wegelin.htm.

Received: $28^{\text {th }}$ October 2018. Accepted: $1^{\text {st }}$ March 2019 